\title{
Abatement of ammonia and butyraldehyde under non-thermal plasma and photocatalysis: Oxidation processes for the removal of mixture pollutants at pilot scale
}

Wala Abou Saoud ${ }^{1,2}$, Aymen Amine Assadi ${ }^{1 *}$, Monia Guiza ${ }^{2}$, Abdelkrim Bouzaza ${ }^{1}$, Wael Aboussaoud $^{2}$, Isabelle Soutrel ${ }^{1}$, Abdelmottaleb Ouederni ${ }^{2}$, Dominique Wolbert ${ }^{1}$, Sami Rtimi ${ }^{3 *}$

${ }^{1}$ Laboratoire Sciences Chimiques de Rennes - équipe Chimie et Ingénierie des Procédés, UMR 6226 CNRS, ENSCR-11, allée de Beaulieu, CS 508307-35708 Rennes, France.

${ }^{2}$ Laboratory process engineering and industrial systems (GPSI), National School of Engineers of Gabes (ENIG), University of Gabes (UG), Omar Ibn Elkhatab Street, Zrig 6029 Gabes, Tunisia.

${ }^{3}$ Ecole Polytechnique Fédérale de Lausanne, EPFL-STI-LTP, Station 12, CH-1015 Lausanne, Switzerland.

* Corresponding author. Tel.: +332 23238152; fax: +33 223238120.

E-mail address: aymen.assadi@ensc-rennes.fr (A. Assadi), sami.rtimi@epfl.ch (S. Rtimi).

\section{Abstract}

Dielectric barrier discharge DBD-plasma based technologies have been widely investigated for the abatement of air pollutants. More recently, photocatalysis $\left(\mathrm{TiO}_{2} / \mathrm{UV}\right.$ lamp) has also showed promising results for air pollution abatement. In this work, these two methods were used separately and combined $\left(\mathrm{TiO}_{2} / \mathrm{UV}\right.$-lamp/DBD-plasma) in order to enhance the performance of the process for air pollutants degradation/mineralization. Ammonia $\left(\mathrm{NH}_{3}\right)$ and butyraldehyde $\left(\mathrm{C}_{4} \mathrm{H}_{8} \mathrm{O}\right)$ have been firstly treated alone and then an equimolar mixture $\left(\mathrm{NH}_{3} / \mathrm{C}_{4} \mathrm{H}_{8} \mathrm{O}\right)$ was monitored in a continuous reactor. Effect of operational parameters such as pollutants inlet concentration, flowrate, humidity and specific energy of plasma were thoroughly determined. Results showed that coupling both methods in the same reactor improves removal efficiency for single pollutant or a mixture of two pollutants. This processes combination showed a synergy between DBDplasma and photocatalytic oxidation. Moreover, pollutant mineralization and potential 
intermediate byproducts have been characterized and discussed. Coupling both processes contributes to enhanced mineralization in comparison with DBD-plasma alone regarding the $\mathrm{CO}_{2}$ selectivity. As for selectivity of byproducts: (i) Relative Humidity $(\mathrm{RH})$, (ii) mixture effect and (iii) $\left(\mathrm{TiO}_{2} / \mathrm{UV}\right.$-lamp/DBD-plasma) combined processes inhibit ozone production during the pollutants removal/oxidation.

Keywords: odorous pollutants, photocatalysis, DBD-plasma, mixture effect, synergetic effect. 


\section{Introduction}

Inorganic compounds such as ammonia and hydrogen sulfide, and a large variety of Volatile Organic Compounds VOCs like aldehydes, ketones, mercaptans, aromatics etc., which are frequently extruded by various industrial and agricultural processes as well as animal husbandry and fertilizer applications [1-3], constitute a significant origin of malodorous air pollutants. These harmful pollutants cause a serious problem which may present a threat to the human health and the environment $[1,2,4]$. Therefore, it is indispensable to reduce its concentration discharge into the atmosphere. Various methods have been largely applied for the remediation of atmospheric pollution such as adsorption [5], thermal and catalytic incineration [6] and bio-filtration [7]. Among these traditional methods, bio-filtration based techniques showed higher efficiency for odor control [8-10], however does have some limitations. The requirement of a large floor surface constitutes one of the major inconveniences which limit its use $[8,9]$.

Alternatively, there is an extensive attention in developing innovative technologies as an efficient and least-cost treatment method [2]. For this purpose, advanced oxidation processes (AOP) such as non-thermal plasma (NTP) [2,4,11,12] and photocatalysis ( $\mathrm{TiO}_{2} /$ external UV-lamp) [13-16] have been proved to be efficient oxidation techniques to purify air pollution. Several studies on $\mathrm{TiO}_{2} / \mathrm{UV}$ oxidation have been investigated to be a promising process for VOCs degradation into nonhazardous mineral species (carbon dioxide and water vapor) $[13,15,17]$. Dielectric barrier discharge DBD-plasma as one of the NTP methods generated by electrical discharge has been extensively applied for removing pollutants including aromatics [18], aldehydes [19], inorganic compounds [20] and mercaptans [21], through of very reactive species created (e.g., $\mathrm{O}^{\circ}$, $\mathrm{HO}^{\circ}$ and $\mathrm{O}_{3}$ ) under ambient conditions (atmospheric pressure and room temperature) $[11,12,22,23]$. Therefore, there is a growing interest in DBD-plasma's activity 
enhancing when combined with photocatalytic process, could acquire synergetic effect and higher efficiency either at pilot or at industrial scale [24-27]. Moreover, a number of studies on dielectric barrier discharge (DBD) plasma-photocatalysis coupling $[25,28,29]$ reveal very interesting prospects on single VOCs oxidation, other than few are being further developed on VOCs mixture treatment.

The Novelty of this work is to follow the degradation behavior of a mixture of contaminants from different nature like organic and inorganic compounds with a high flow. In this study, butyraldehyde $\left(\mathrm{C}_{4} \mathrm{H}_{8} \mathrm{O}\right)$ and ammonia $\left(\mathrm{NH}_{3}\right)$ were selected as model molecules. Photocatalysis $\left(\mathrm{TiO}_{2} / \mathrm{UV}\right.$-lamp) and dielectric barrier discharge DBD-plasma are applied simultaneously in a continuous reactor to properly appraise the performance of the system on pollutants removal and mineralization. Effect of experimental conditions on ozone formation inside the DBD-plasma reactor wasalso studied and discussed. In addition, at pilot scale, the synergistic effect resulting from the combination of DBD-plasma and photocatalysis $\left(\mathrm{TiO}_{2} / \mathrm{UV}\right.$-lamp) was determined under equimolar mixture condition. Finally, butyraldehyde alone and in equimolar mixture with ammonia $\left(\mathrm{NH}_{3} / \mathrm{C}_{4} \mathrm{H}_{8} \mathrm{O}\right)$ intermediate by-products are identified.

\section{Experiment and measurement}

\subsection{Experimental setup}

The experimental setup designed to study the coupling between DBD-plasma and $\left(\mathrm{TiO}_{2}\right.$ /external UV-lamp) photocatalysisis shown in Figure 1(a). The processis equipped with a polluted air generation system, cylindricalreactor, gas sampling equipment and analysis systems. The $\left(\mathrm{TiO}_{2} / \mathrm{UV}\right)$-DBD reactor consists of two concentric cylinders one outer cylinder of $76 \mathrm{~mm}$ and an inner cylinder of $58 \mathrm{~mm}$ (Figure 1(b)) with wall thickness of $4 \mathrm{~mm}$, both $100 \mathrm{~cm}$ long. Glass Fiber Tissue (GFT) was coated withTiO $\mathrm{T}_{2}$ as performed 
by Ahlstrom Research and Services.It is maintained on the inner reactor wall by the stainless steel grid electrode. It can be simultaneously submitted to surface DBD-plasma and UV irradiation. Thus, UV lamp is placed in the inner concentric cylinder in order to have a homogeneous irradiation. To generate DBD-plasma, high voltage power is applied to the reactor which is covered by a copper grid forming the outer electrode and the inner is on aluminum. The applied voltage is delivered by a generator as a sinusoidal waveform up to $10 \mathrm{~V}$ and then amplified by an amplifier to achieve $30 \mathrm{kV}$. More details about the electrical system of the DBD-plasma reactor has been described in detail in a previous work [30]. The polluted air generation was performed according to the same methodologies as applied in our previous study [21]. The pollutants, butyraldehyde $\left(\mathrm{C}_{4} \mathrm{H}_{8} \mathrm{O}\right)$ and ammoniac $\left(\mathrm{NH}_{3}\right)$, are injected continuously in liquid state (from a pure liquid $99.9 \%$ and $20 \%$ aqueous solution, respectively) by means of a syringe-syringe driver system (Kd Scientific Model 100) (Figure 1(a)).

\subsection{Pollutants and by-products identification}

Initial concentration of butyraldehyde and ammonia, gas flowrate, and relative humidity were monitored. A concentration ranging from 0.5 to $4 \mathrm{mmol} \mathrm{m}^{-3}$ was achieved by regulating the mass flow meter (Bronkhorst In-Flow). For experiments under humid condition, a portion of the air flow is derived through a packed column where water flows in counter current and the relative humidity value ranging from 5 to $90 \%$. Temperature and relative humidity $(\mathrm{RH})$ are determined using a specific sensor (Testo 445). Butyraldehyde concentration during each test was measured manually with a syringe of $500 \mu \mathrm{L}$ using a gas chromatography (Fisons GC9000) equipped with a flame ionization detector (GC-FID), whereas to identify the by-products formed during the experiments, a Gas Chromatograph-Mass Spectrometer (GC-MS) coupled to an infrared (IR) detector was used. $\mathrm{NH}_{3}$ concentration was determined via spectrophotometric method using 
Nessler reagent. Ammonia in gas stream bubbles through a chloric acid $(\mathrm{HCl})$ solution at $10^{-1} \mathrm{M}$, where it is absorbed as ammonium ion $\mathrm{NH}_{4}$ reacting with Nessler reagent to obtain colored solution. Ammoniac concentration was then determined by measuring light absorbance at $420 \mathrm{~nm}$ with a spectrophotometer. The plot of absorbance with the amount of $\mathrm{NH}_{3}$ in solution obeyed to a linear relationship with a correlation coefficient of 0.997. The ozone concentration was monitored by iodometric titration method, Thus, outlet air flow is bubbled in a potassium iodide $(\mathrm{KI})$ solution at $10^{-2} \mathrm{M}$, until a yellow color emerges. The sample is then titrated with sodium thiosulfate solution $\left(\mathrm{Na}_{2} \mathrm{~S}_{2} \mathrm{O}_{3}\right)$ at $10^{-2} \mathrm{M}$ until a colorless solution is obtained [31]. All experiments were operated under ambient conditions (atmospheric pressure and ambient temperature).

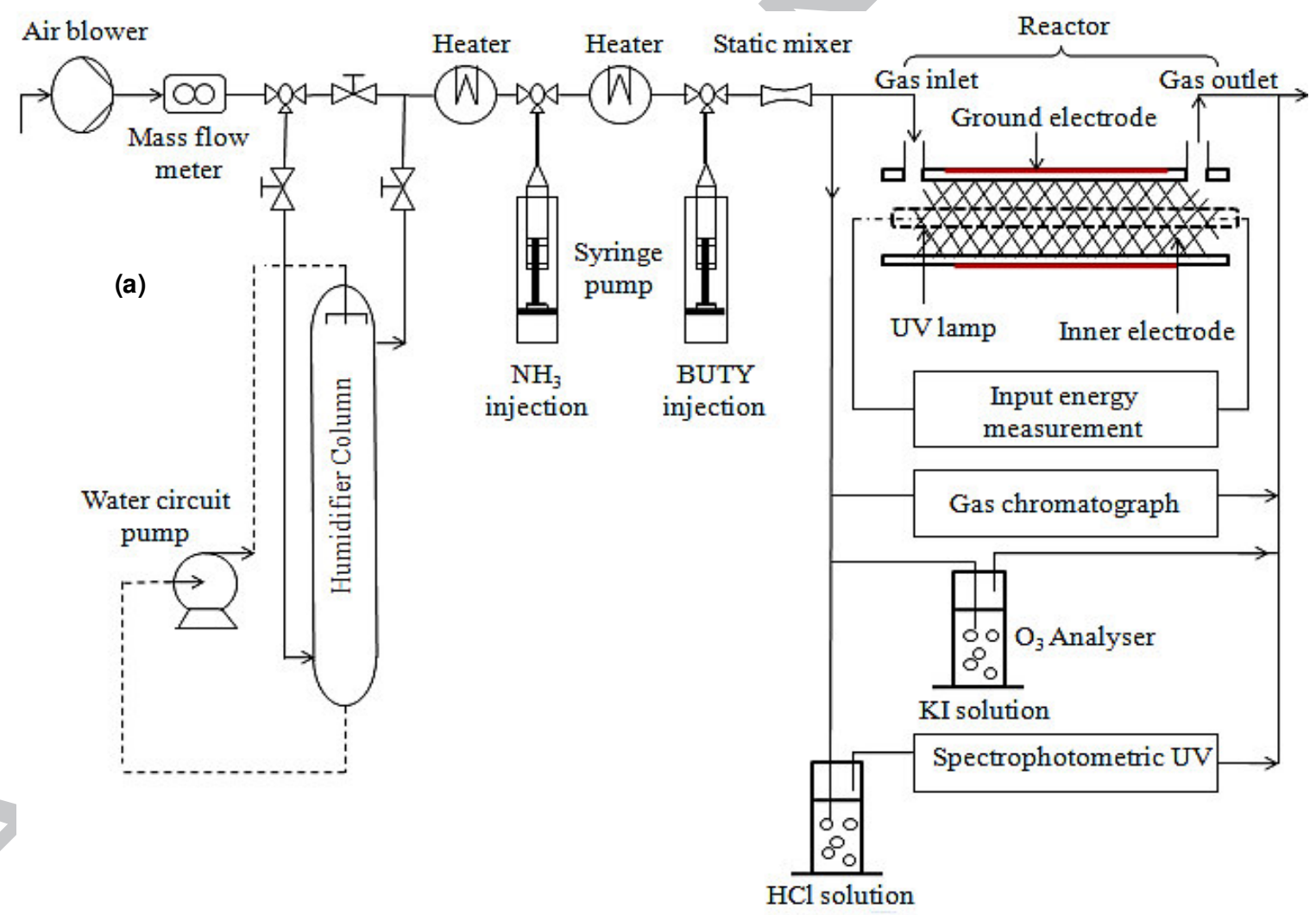


(b)

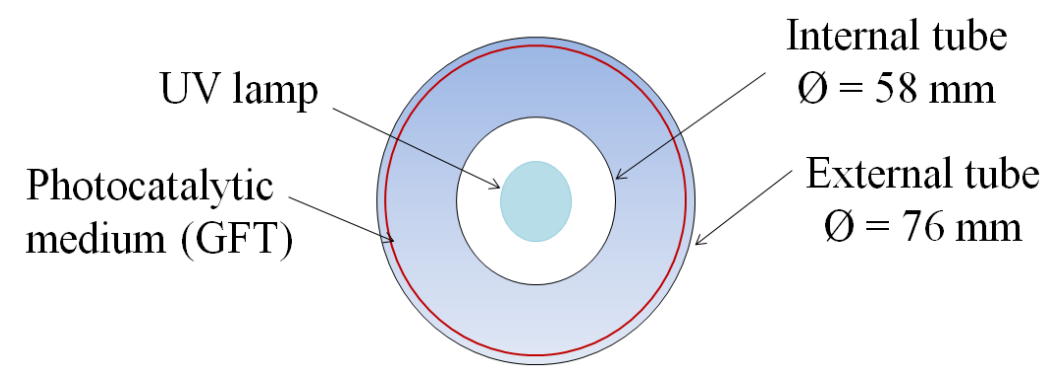

Figure 1. Schematic (a) of the experimental setup and sectional drawing (b) of the annular reactor

\subsection{Analytic methods}

Process performance was evaluated by measuring:

- Inlet $\left[\mathrm{C}_{\mathrm{in}}\right]$ and outlet $\left[\mathrm{C}_{\text {out }}\right]$ concentrations of pollutants

- Removal efficiency of pollutants: $\operatorname{RE}(\%)=\frac{\left(\left[\mathrm{C}_{\text {in }}\right]-\left[\mathrm{C}_{\text {out }}\right]\right) \times 100}{\left[\mathrm{C}_{\text {out }}\right]}(1)$

- Specific input energy: $\operatorname{SIE}\left(\mathrm{J} \mathrm{L}^{-1}\right)=\frac{3600 * \mathrm{P}(\mathrm{W})}{\mathrm{Q}\left(\mathrm{m}^{3} \mathrm{~h}^{-1}\right) \times 1000}(2)$

where $P$ is input power adjusted by changing the applied voltage $\left(U_{a}\right)$ and $Q$ is the flowrate.

- Selectivity of CO: SCO (\%) $=\frac{\left[\mathrm{CO}_{\text {out }}\right]-\left[\mathrm{CO}_{\text {in }}\right]}{4 \times \mathrm{RE}(\%) \times\left[\mathrm{C}_{\text {in }}\right]} * 10000(3)$

- Selectivity of $\mathrm{CO}_{2}: \mathrm{SCO}_{2}(\%)=\frac{\left[\mathrm{CO}_{2 \text { out }}\right]-\left[\mathrm{CO}_{2 \text { in }}\right]}{4 \times \mathrm{RE}(\%) \times\left[\mathrm{C}_{\text {in }}\right]} * 10000(4)$

\subsection{Surface atomic concentration as by X-ray Photoelectron Spectroscopy (XPS)}

The surface atomic concentration of the species existing in the top most layers of the tissue were evaluated using XPS as previously described [32]. An AXIS NOVA photoelectron spectrometer (Kratos Analytical, Manchester, UK) equipped with monochromatic Al Ka $(\mathrm{hm}=1486.6 \mathrm{eV})$ anode was used during the study. The carbon 
C1s line with position at $284.6 \mathrm{eV}$ was used as a reference to correct the charging effects. The surface atomic concentration of elements was determined from peak areas using known sensitivity factors [33]. Spectrum background was subtracted according to Shirley [34]. The applied subtraction was Gaussian-Lorentzian 30 (GL(30)). The XPS spectra of the species were analyzed by mean of spectra deconvolution Casa XPS software. The samples were kept in flasks previously flushed with Argon to reduce the risk of contamination and reactivity after the experiment.

\section{Results and discussion}

Degradation of ammonia and butyraldehyde was studied as single compounds as well as equimolar mixture with ammoniac. Photocatalytic experiments with external UV source $\left(\mathrm{TiO}_{2} / \mathrm{UV}\right.$-lamp) were done first, then the DBD-plasma was studied without external UV lamp, and finally the combination of photocatalysis and plasma $\left(\mathrm{TiO}_{2} / \mathrm{UV}\right.$ lamp/DBD-plasma) in the same reactor was studied.

\subsection{Study of monocompound system}

\subsubsection{Effects of inlet concentration and flowrate on photocatalytic oxidation}

To determine the performance of the photocatalytic oxidation, the influence of some process parameters should be clearly defined. For this purpose, the effects of inlet pollutants concentration and gas flowrate were investigated. Figure 3 shows the removal efficiency (RE) of butyraldehyde and ammonia using a photocatalytic reactor. The experiments were performed ranging from 0.6 to $4 \mathrm{mmol} \mathrm{m}^{-3}$ for two different flowrates i.e. 1 and $2 \mathrm{~m}^{3} \mathrm{~h}^{-1}$. It was observed, that by increasing the flow rate, the removal efficiency of two pollutants decreased as it is readily seen in Figure 3. This can be attributed to the decrease in the contact time between the pollutant and the catalytic active sites. This leads to a reduced amount of pollutants able to react with active 
species attached to the surface. Photocatalytic degradation of butyraldehyde and ammonia clearly decreased as inlet concentration increased. However, higher concentration increases the quantity of pollutants in the reactor which potentially limits the degradation under the same experimental condition (amount of catalysts and UV intensity). Hence, efficiencies decrease at higher concentrations as reported in literature $[21,35]$. As for ammonia, results indicate that the RE remains low ( 38\%) compared to butyraldehyde and that category of inorganic compound is very hard to degrade by photocatalytic oxidation by itself. Moreover, this behavior can be attributed to the molar mass of butyraldehyde hampering the adsorption and thus the photocatalytic oxidation.

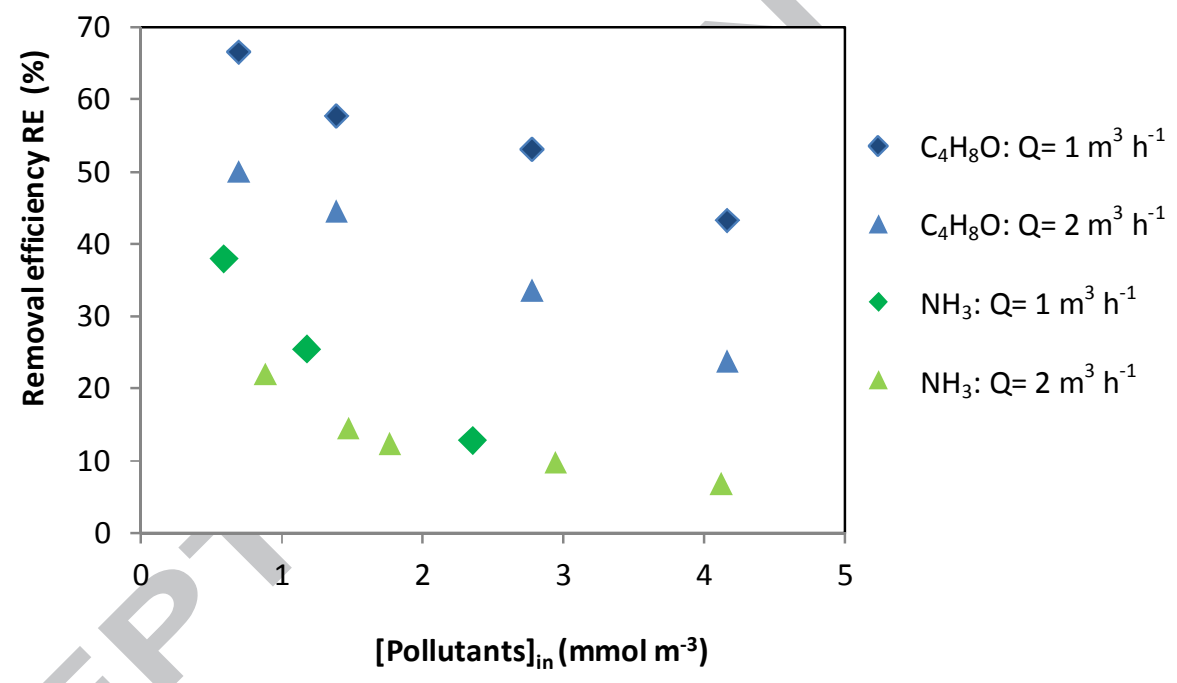

Figure 3. Variation of removal efficiency $(R E)$ of butyraldehyde and ammonia with inlet concentration at different flow rates $\left(\mathrm{T}=20^{\circ} \mathrm{C}, \mathrm{UV}\right.$ intensity $\left.=20 \mathrm{~W} \mathrm{~m}^{-2}, \mathrm{RH}=55-60 \%\right)$

\subsubsection{Effect of humidity on the photocatalytic oxidation}

Humidity constitutes also an important parameter that can directly affect the trend of gas-phase photocatalytic reactions. Thus, the influence of relative humidity on butyraldehyde removal using photocatalysis was studied and to understand its effect, three various relative humidity conditions were controlled (dry air, medium humidity $50 \%$, and high humidity $90 \%$ ) at different butyraldehyde inlet concentrations. The results 
are shown in Figure 4. The presence of water molecules in the air stream improves butyraldehyde oxidation for either values of inlet concentration. Under dry condition $(\mathrm{HR}=50 \%)$, the $\left(\mathrm{C}_{4} \mathrm{H}_{8} \mathrm{O}\right)$ removal efficiency was $44 \%$ and reached an optimum of $56 \%$ at $1.4 \mathrm{mmol} \mathrm{m} \mathrm{m}^{-3}$ of $\left(\mathrm{C}_{4} \mathrm{H}_{8} \mathrm{O}\right)$. However, the slight increase of humidity helps the photogeneration of hydroxyl radical $\mathrm{HO}^{\circ}$ as very reactive specie, leading to an enhancement in the VOCs degradation. When moisture increases, the competitive effect between water molecules and pollutants on active sites becomes more important which causes a decrease of removal efficiency. At initial concentration of $4 \mathrm{mmol} \mathrm{m}^{-3}$, it can be noted that in the case of high humidity $(\mathrm{RH}=90 \%)$, the $\left(\mathrm{C}_{4} \mathrm{H}_{8} \mathrm{O}\right)$ degradation decreased of $50 \%$ compared to $45 \% \mathrm{RH}$. This trend can be due to the competition between water vapor and butyraldehyde to adsorb on the active sites of the photocatalytic surface. We note also that, whatever the inlet pollutant concentration increases, the removal rate increases at low $\mathrm{RH}$. Hence, based on these results, the optimal water vapor value was found to be $50 \%$. It was shown by Martinez et al. that the increase of humidity beyond an optimal level decreases BTEX photocatalytic degradation [36]. Assadi et al., obtained similar results when they studied the isovaleric acid degradation [30].

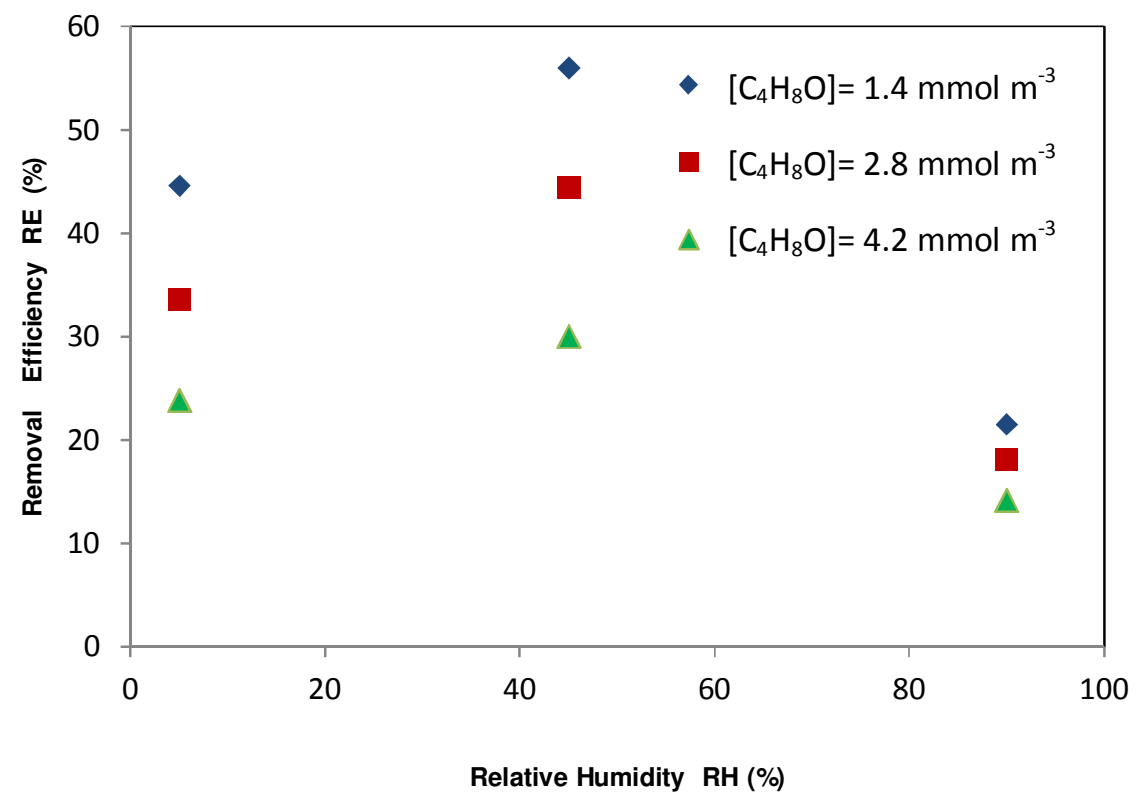

Figure 4. Variation of butyraldehyde removal efficiency with the inlet concentration at different values of relative humidity $\left(T=20^{\circ} \mathrm{C}, \mathrm{Q}=2 \mathrm{~m}^{3} \mathrm{~h}^{-1}\right)$

\subsubsection{Effect of the specific input energy increase on pollutants removal}


Figure 5 shows the effect of specific energy of DBD-plasma generated in the reactor on the butyraldehyde and ammonia degradation (separately). The experiments were carried out by coupling DBD-plasma with photocatalysis $\left(\mathrm{TiO}_{2} / \mathrm{UV}\right.$-lamp) under dry conditions and continuous flow of $2 \mathrm{~m}^{3} \mathrm{~h}^{-1}$ for the specific input energy (SIE) range of 9$18 \mathrm{JL}^{-1} . \mathrm{C}_{4} \mathrm{H}_{8} \mathrm{O}$ and $\mathrm{NH}_{3}$ removal efficiencies, using both processes together $\left(\mathrm{TiO}_{2} / \mathrm{UV}\right.$ lamp/DBD-plasma) with an initial concentration of $2 \mathrm{mmol} \mathrm{m}^{-3}$, as a function of the sum of removal efficiency due to DBD-plasma and photocatalysis are represented in Figure 5. Increasing the SIE from 9 to $18 \mathrm{JL}^{-1}$ leads to an improvement in $\mathrm{C}_{4} \mathrm{H}_{8} \mathrm{O}$ and $\mathrm{NH}_{3}$ removal efficiencies. This can be explained by the high-energy values and the electric discharges producing more reactive species, which may contribute to the improvement of pollutant degradation. In Figure 5, the bisector-line was set to compared the removal efficiency obtained by coupling plasma and photocatalysis (vertical axis) to the results obtained by the sum of removal efficiencies by plasma process alone or photocatalytic process alone (horizontal axis). If there is no synergistic effect when coupling both plasma and photocatalysis, or if there is a negative effect, the points have to be confused with the bisector $\left(Y_{\text {axis }}=X_{\text {axis }}\right)$ or below it. The points obtained are above the bisector, wish means that there is a positive effect when coupling both processes. Comparing the combined processes $\left(\mathrm{TiO}_{2} / \mathrm{UV}\right.$-lamp/DBD-plasma) with photocatalysis and DBD-plasma separately, results show that the coupling exhibits higher performance, which is greater than the sum of DBD-plasma alone and photocatalysis alone (Figure 5). For instance, at $\operatorname{SIE}=15 \mathrm{JL}^{-1}$, the rate of butyraldehyde removal efficiency obtained by combined processes reached $57.71 \%$, whereas the sum of RE by DBD-plasma and photocatalysis is $47.88 \%$. As for ammonia, the degradation rate was $59.26 \%$ when applying $\mathrm{TiO}_{2} / \mathrm{UV}$-lamp/DBD-plasma with respect to $52.5 \%$ of the sum of both processes. In this case, we note an enhancement of $7-10 \%$ on removal efficiency. 
Results indicate that, whatever the pollutant used, there is a strong synergy between both processes. Hence, plasma can greatly contribute to the desorption of the degraded byproducts adsorbed on $\mathrm{TiO}_{2}$ surface through the active species which leads to increase catalytic activity of $\mathrm{TiO}_{2}$ and consequently, improves its photocatalytic degradation.

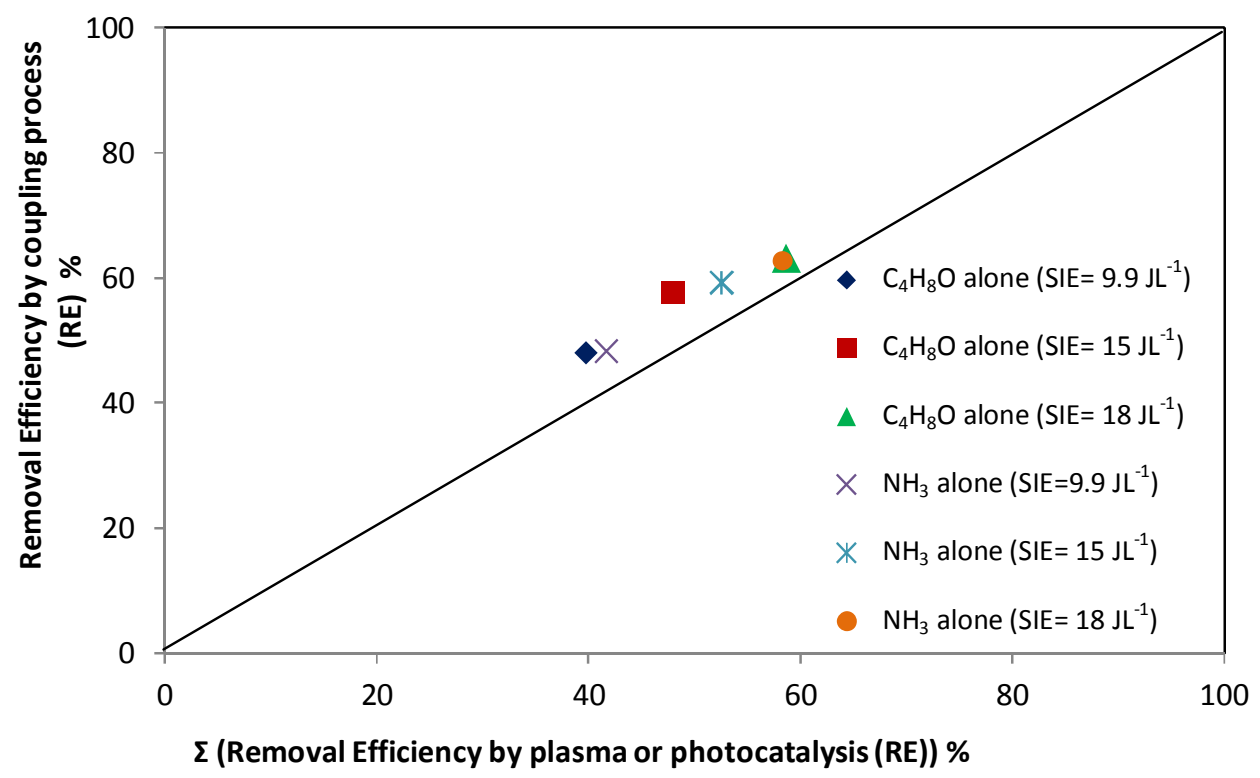

Figure 5. Variation of butyraldehyde and ammonia removal efficiency with SIE using three processes $\left(\mathrm{Q}=2 \mathrm{~m}^{3} \mathrm{~h}^{-1},[\mathrm{BUTY}]=\left[\mathrm{NH}_{3}\right]=2 \mathrm{mmol} \mathrm{m}{ }^{-3}, \mathrm{RH}=5 \%\right)$

\subsection{Study of the removal of gas mixture system}

\subsubsection{Effect of initial concentration increase on photocatalytic oxidation}

The aim here was to compare the behavior of butyraldehyde and ammonia degradations when treated separately, to the behavior when both gazes are mixed. In this experiment, $\mathrm{C}_{4} \mathrm{H}_{8} \mathrm{O}, \mathrm{NH}_{3}$ and their mixture degradations under photocatalytic oxidation were carried out at inlet gas concentration range from 1 to $4.5 \mathrm{mmol} \mathrm{m}-3$ under a flowrate of $2 \mathrm{~m}^{3} \mathrm{~h}^{-1}$. Figure 6 shows that photocatalytic removal efficiency of $\mathrm{C}_{4} \mathrm{H}_{8} \mathrm{O}$ and $\mathrm{NH}_{3}$ decreases in the case of $\left(\mathrm{C}_{4} \mathrm{H}_{8} \mathrm{O} / \mathrm{NH}_{3}\right)$ mixture treatment. It is likely that this is related to the 
competition adsorption of pollutants on the photocatalysts active sites. This behavior is similar to what it was reported by Debono et al. [37]. The latter evidenced the inhibitive effect along the photocatalytic degradation of three VOCs mixture. Indeed, Figure 6 indicates that $\left(\mathrm{C}_{4} \mathrm{H}_{8} \mathrm{O} / \mathrm{NH}_{3}\right)$ mixture considerably affects $\mathrm{C}_{4} \mathrm{H}_{8} \mathrm{O}$ degradation compared to $\mathrm{NH}_{3}$ degradation. The removal efficiency drop from $45 \%\left(\mathrm{C}_{4} \mathrm{H}_{8} \mathrm{O}\right)$ and $15 \%\left(\mathrm{NH}_{3}\right)$, when each gas was tested alone, to $33 \%\left(\mathrm{C}_{4} \mathrm{H}_{8} \mathrm{O}\right)$ and $12 \%\left(\mathrm{NH}_{3}\right)$ when both used together.

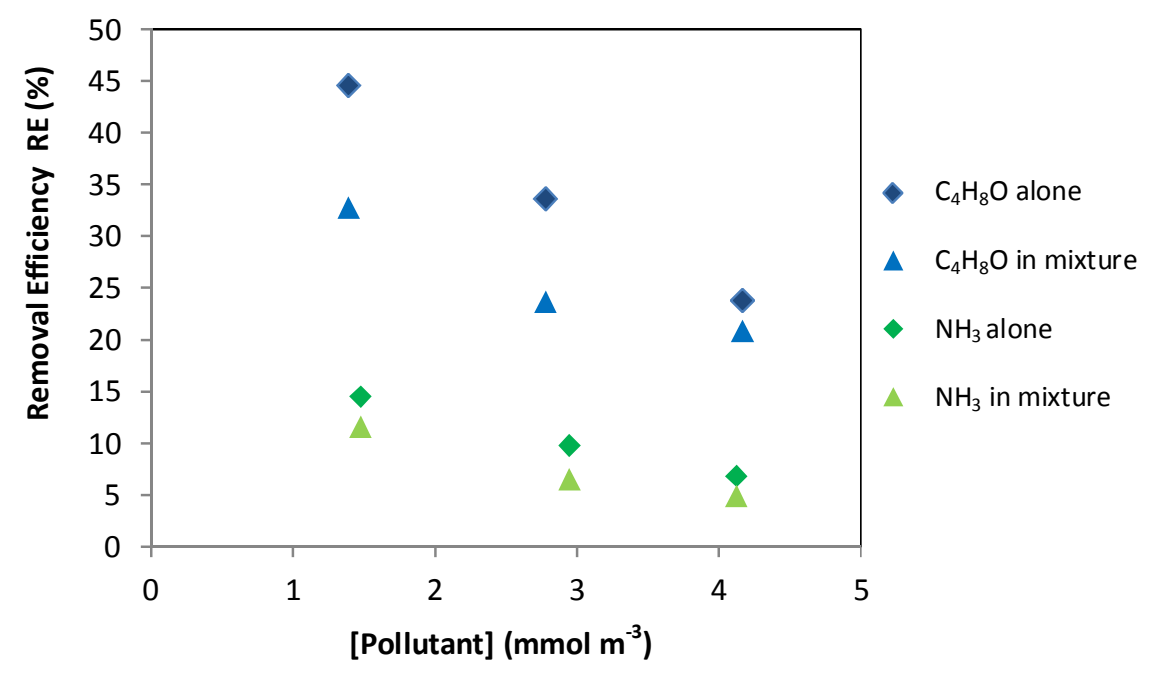

Figure 6. Effect of mixture on removal efficiency of butyraldehyde and ammonia

$$
\left(T=20{ }^{\circ} \mathrm{C}, \mathrm{Q}=2 \mathrm{~m}^{3} \mathrm{~h}^{-1}, \mathrm{HR}=55-60 \%\right)
$$

\subsubsection{Effect of SIE increase on mixture oxidation}

Figure 7 shows the $\mathrm{C}_{4} \mathrm{H}_{8} \mathrm{O} / \mathrm{NH}_{3}$ mixture degradation at a flow rate of $2 \mathrm{~m}^{3} \mathrm{~h}^{-1}$ and a concentration of $2 \mathrm{mmol} \mathrm{m}^{-3}$ under photocatalysis, DBD-plasma and their combination. It is readily seen that an increase of the specific energy from 9 to $18 \mathrm{JL}^{-1}$ enhances the removal efficiency independently of the nature of the pollutant. The removal efficiency rise from $16 \%\left(\mathrm{C}_{4} \mathrm{H}_{8} \mathrm{O}\right)$ and $32 \%\left(\mathrm{NH}_{3}\right)$, for an $\mathrm{SIE}=9 \mathrm{JL}^{-1}$, to $28 \%\left(\mathrm{C}_{4} \mathrm{H}_{8} \mathrm{O}\right)$ and $51 \%$ $\left(\mathrm{NH}_{3}\right)$, for an $\mathrm{SIE}=18 \mathrm{JL}^{-1}$. Lu et al. have compared the decomposition of ammonia and hydrogen sulfide using non-thermal plasma reactor [38]. They reported that removal 
efficiencies of $\mathrm{NH}_{3}$ and $\mathrm{H}_{2} \mathrm{~S}$ strongly depend on the applied voltage. It was observed that boosting energy improves the level of electrons, which enhances the production of reactive radicals and consequently leads to greater degradation efficiency. These observations are in agreement with other studies [39,40]. Figure 7 shows that compared to the photocatalytic oxidation, the removal efficiency of ammonia by DBD-plasma is clearly more effective than to photocatalysis. It should be noted from Figure 7 that coupling ( $\mathrm{TiO}_{2} / \mathrm{UV}$-lamp/DBD-plasma) significantly enhances the removal efficiencies of $\mathrm{C}_{4} \mathrm{H}_{8} \mathrm{O}$ and $\mathrm{NH}_{3}$. In the case of $\left(\mathrm{C}_{4} \mathrm{H}_{8} \mathrm{O} / \mathrm{NH}_{3}\right)$ mixture, results show that the synergetic effect observed for the system " $\mathrm{TiO}_{2} / \mathrm{UV}$-lamp/DBD-plasma" was significantly better for ammonia than that for butyraldehyde. Thus, when photocatalysis was used, just $7 \%$ of the $\mathrm{C}_{4} \mathrm{H}_{8} \mathrm{O}$ was decomposed. During DBD-plasma process, at $\mathrm{SIE}=18 \mathrm{JL}^{-1}$ and without external UV-lamp, BUTY removal reached to $28 \%$ and when coupling photocatalysis with DBD-plasma, the BUTY removal increased to $40 \%$. Regarding ammonia, at the same applied energy $\left(18 \mathrm{JL}^{-1}\right)$, it can be noted that the removal efficiency of ammonia was around $20 \%$ for photocatalysis, reaches $51 \%$ for DBD-plasma and increased to $83 \%$ for coupling photocatalysis and DBD-plasma.

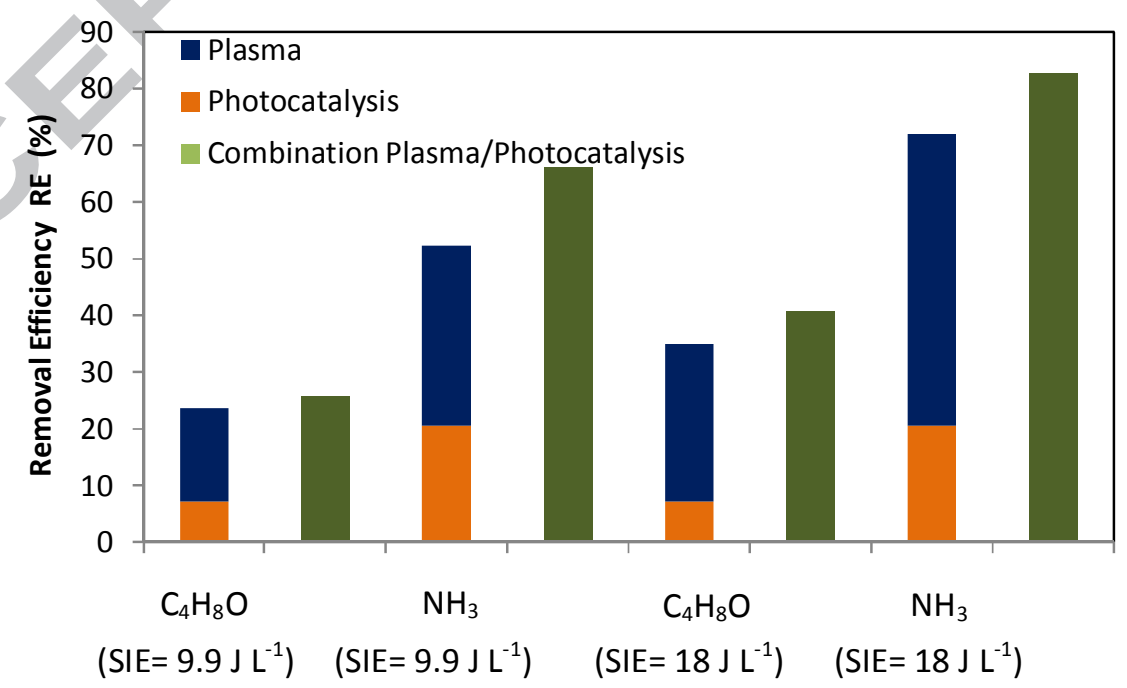


Figure 7. Variation of the removal efficiency of BUTY and ammonia in mixture with SIE using the three processes $\left(\mathrm{Q}=2 \mathrm{~m}^{3} \mathrm{~h}^{-1},[\right.$ Mixture $\left.]=2 \mathrm{mmol} \mathrm{m}^{-3}, \mathrm{RH}=5 \%\right)$

\subsection{Ozone formation, $\mathrm{CO}$ and $\mathrm{CO}_{2}$ selectivity's and intermediates identification}

\subsubsection{Ozone formation}

Ozone is considered a primary by-product generated under DBD-plasma reactor. To investigate the effect of relative humidity and UV irradiation on ozone formation, the concentration of ozone at the outlet of the reactor was monitored at various energy densities. Figure 8 shows the ozone concentration measured either under DBD-plasma alone or when coupling photocatalysis $\left(\mathrm{TiO}_{2} / \mathrm{UV}\right.$ lamp) with plasma under dry or humid conditions. The results show that humidity strongly affected ozone production in the reactor. At high humidity ( $\mathrm{HR}=90 \%)$, ozone concentration is strongly decreased whether for DBD-plasma or when coupling DBD-plasma with photocatalysis. Ozone concentration drop from 30ppm (DBD-plasma) and 23ppm ( $\mathrm{TiO}_{2} / \mathrm{UV}$-lamp/DBDplasma), under dry condition, to 6ppm (DBD-plasma) and 5ppm ( $\mathrm{TiO}_{2} / \mathrm{UV}$-lamp/DBDplasma) under high humidity for $\mathrm{SIE}=18 \mathrm{JL}^{-1}$. This lower ozone concentration can be attributed to the fact that ozone can be decomposed by the photo-generated radicals $\left(\mathrm{H}^{\circ}, \mathrm{HO}^{\circ}\right)$ created at the photocatalyst interface according to equation 5-7 below $[40,41]$, leading to its very. In the same way, adding photocatalysis ( $\mathrm{TiO}_{2} / \mathrm{UV}$-lamp) to DBDplasma led to ozone removal. Thus, for its decomposition into very reactive species $\left(\mathrm{O}_{2}^{\circ-}\right.$ and $\left.\mathrm{HO}_{2}{ }^{\circ}\right)$, ozone requires highly energetics photons, mainly UV [21].

$$
\mathrm{H}_{2} \mathrm{O}+\mathrm{e}^{-} \longrightarrow \mathrm{H}^{\cdot}+\mathrm{HO}^{-}+\mathrm{e}^{-}
$$


$\mathrm{O}_{3}+\mathrm{OH}^{-} \longrightarrow \mathrm{O}_{2}+\mathrm{HO}_{2}$

$\mathrm{O}_{3}+\mathrm{H}^{\cdot} \longrightarrow \mathrm{O}_{2}+\mathrm{OH}^{\cdot}$
(6)

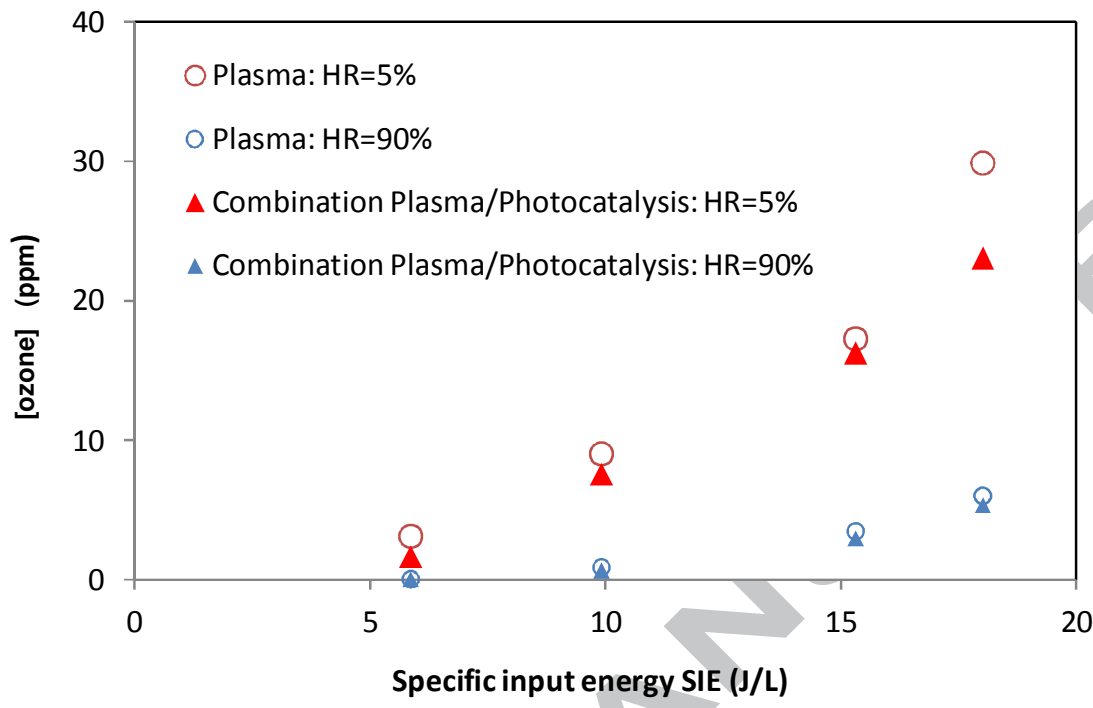

Figure 8. Effect of relative humidity on ozone formation with SIE using DBD-plasma and combination process

\subsection{2. $\mathrm{CO}$ and $\mathrm{CO}_{2}$ selectivity's and intermediates identification}

$\mathrm{CO}$ and $\mathrm{CO}_{2}$ selectivity were measured when applying photocatalysis, DBD-plasma and their combination for $\left(\mathrm{C}_{4} \mathrm{H}_{8} \mathrm{O} / \mathrm{NH}_{3}\right)$ mixture degradation. Figure 9 shows that carbon dioxide $\left(\mathrm{CO}_{2}\right)$ is the dominant product detected through all experiments. Hence, $\mathrm{CO}_{2}$ reached the highest selectivity for photocatalysis with a rate of $72 \%$ against $45 \%$ for plasma and $56 \%$ for the combination DBD-plasma and photocatalysis. Regarding carbon monoxide CO, Figure 9 shows that $\mathrm{CO}$ selectivity measured at the outlet of the reactor under combined processes became lower with a mineralization rate of less than $8 \%$. In order to better understand the degradation pathways of $\left(\mathrm{C}_{4} \mathrm{H}_{8} \mathrm{O} / \mathrm{NH}_{3}\right)$ mixture, all other by-products generated under the combined processes $\left(\mathrm{TiO}_{2} / \mathrm{UV}\right.$-lamp/DBDplasma) were identified by Gas Chromatograph-Mass Spectrometer (GC-MS). All 
samples are concentrated immediately on a Carbotrap $(25 \mathrm{ml})$ and then removed by thermal desorption unit coupled with GC-MS. The chromatograms are shown in Figure 10. The detected by-products were essentially: butyric acid $\left(\mathrm{C}_{4} \mathrm{H}_{8} \mathrm{O}_{2}\right)$, propionic acid $\left(\mathrm{C}_{3} \mathrm{H}_{6} \mathrm{O}_{2}\right)$, butyramide $\left(\mathrm{C}_{4} \mathrm{H}_{9} \mathrm{NO}\right)$, propanamide $\left(\mathrm{C}_{3} \mathrm{H}_{7} \mathrm{NO}\right)$ and acetic acid $\left(\mathrm{C}_{2} \mathrm{H}_{4} \mathrm{O}_{2}\right)$. Consequently, according to these results, the mechanism for $\left(\mathrm{C}_{4} \mathrm{H}_{8} \mathrm{O} / \mathrm{NH}_{3}\right)$ mixture removal when using the combined processes $\left(\mathrm{TiO}_{2} / \mathrm{UV}\right.$-lamp/DBD-plasma) is suggested in Figure 11. Abou Ghaida et al. have studied the decomposition of butyraldehyde as pure compound by coupling surface dielectric barrier discharge and photocatalysis in continuous reactor [22].

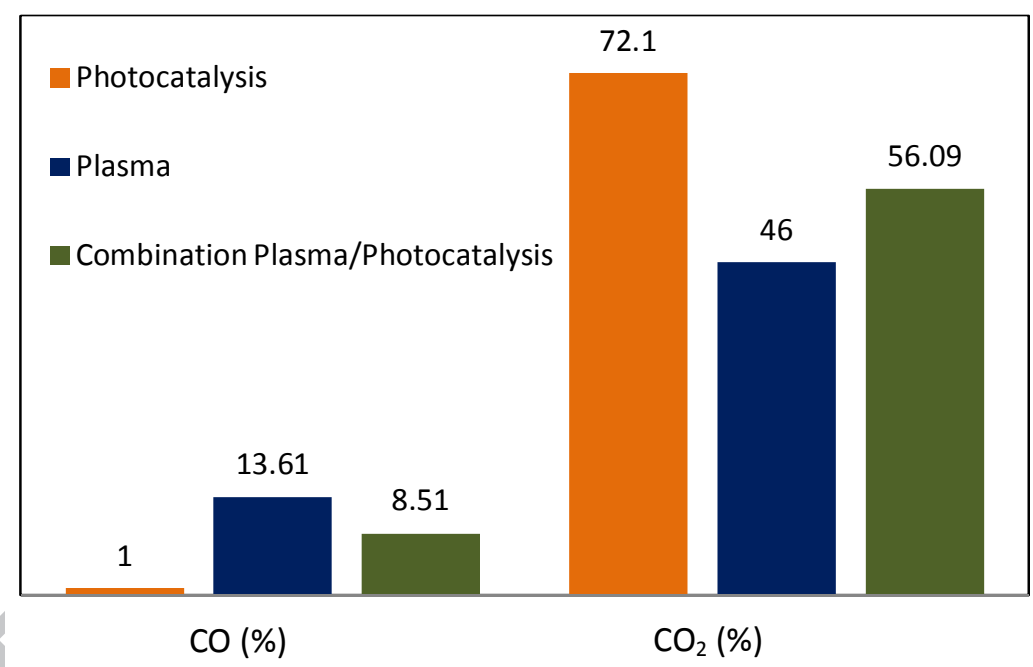

Figure 9. Variation of $\mathrm{CO}_{x}$ selectivity (\%) when applying the three processes $\left(\mathrm{Q}=2 \mathrm{~m}^{3} \mathrm{~h}^{-1}\right.$, [Mixture] $\left.=2 \mathrm{mmol} \mathrm{m}^{-3}, \mathrm{SIE}=9.9 \mathrm{~J} \mathrm{~L}^{-1}, \mathrm{RH}=5 \%\right)$. 


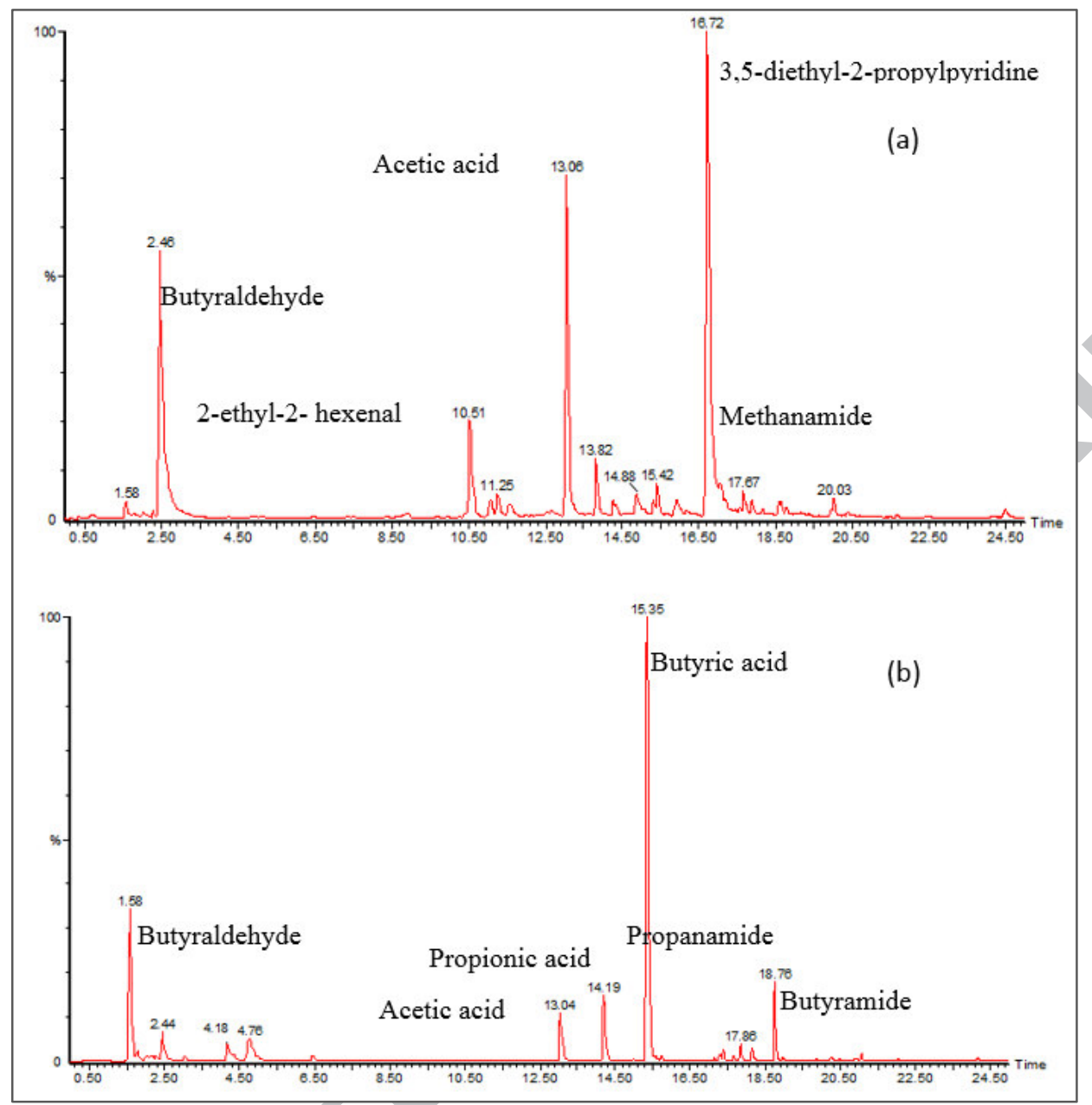

Figure 10. By-products identified by GC-MS for mixture degradation when applying photocatalysis and coupling DBD-plasma/photocatalysis: (a) Process tested: photocatalysis, (b) Process tested: DBD-plasma/photocatalysis $\left(\mathrm{Q}=2 \mathrm{~m}^{3} \mathrm{~h}^{-1}\right.$, [Mixture] $=2 \mathrm{mmol} \mathrm{m}{ }^{-3}, \mathrm{SIE}=9.9 \mathrm{~J} \mathrm{~L}^{-1}$, $\mathrm{RH}=5 \%)$ 


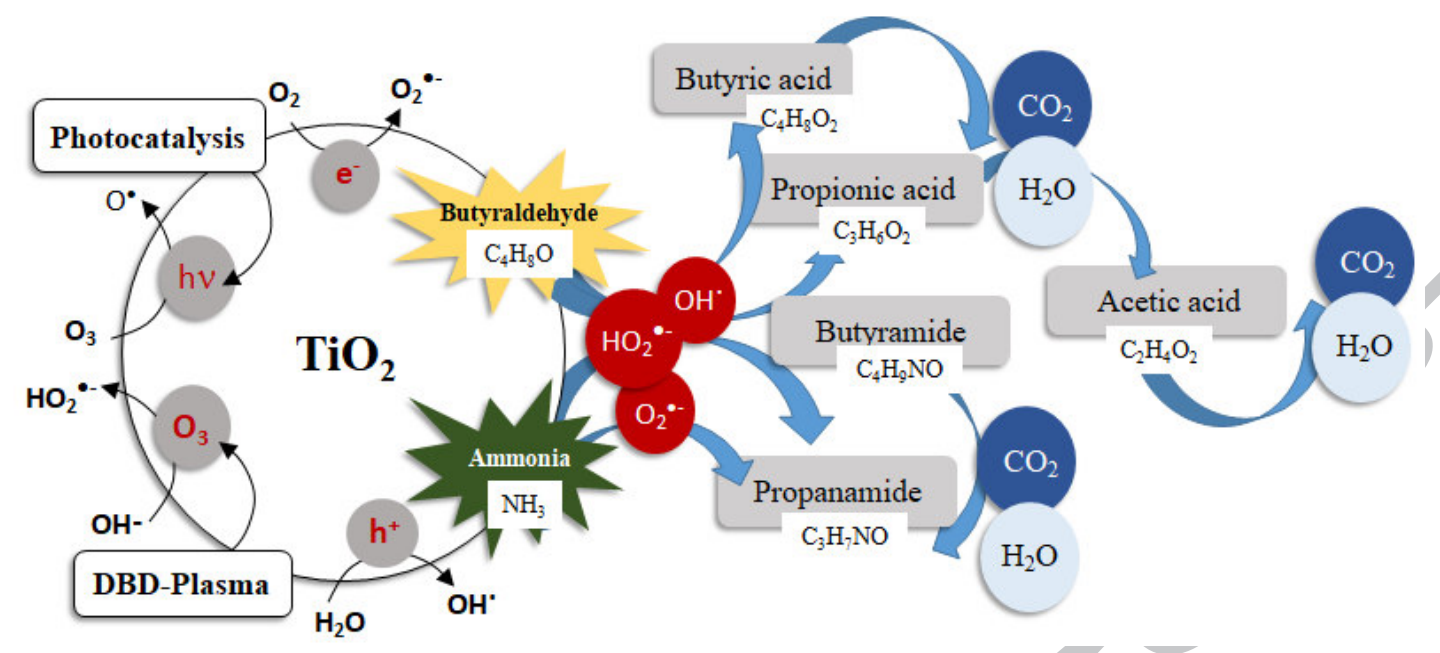

Figure 11. Suggested mechanism for $\left(\mathrm{C}_{4} \mathrm{H}_{8} \mathrm{O} / \mathrm{NH}_{3}\right)$ mixture removal under $\mathrm{TiO}_{2} / \mathrm{UV}$-lamp/DBDplasma combined processes.

\subsubsection{Catalyst poisoning and process sustainability}

The surface atomic concentrations of elements before and after the mixture decomposition were investigated by XPS. Table 1 shows the catalyst poisoning before the treatment and after the effect of the combined processes [21]. It is readily shown that the combined processes $\left(\mathrm{TiO}_{2} / \mathrm{UV}\right.$-lamp/DBD-plasma) degraded the mixture pollutants and reduced the surface poisoning. This is seen after the poisoning of the catalyst especially for the surface atomic concentration of carbon and nitrogen species, which decrease after the pollutants degradation and mineralization as seen in Table 1. It has been reported that during the photocatalytic oxidation, some carboxylic acid intermediated can be formed and rapidly mineralized to $\mathrm{CO}_{2}$ and $\mathrm{H}_{2} \mathrm{O}$ by photo-Kolbe reaction [42]. 
Table 1. Surface percentage atomic concentration on the catalyst surface at time zero, after the catalyst poisoning and after the plasma treatment: evidence for surface regeneration.

\begin{tabular}{|l|c|c|c|c|c|}
\hline & Ti2p & Si2p & O1s & C1s & N1s \\
\hline At time zero & 27.41 & 22.63 & 28.74 & 21.19 & 0.02 \\
\hline Poisoned catalyst & 20.32 & 18.16 & 24.99 & 25.78 & 10.69 \\
\hline After DBD-plasma + photocatalysis & 27.33 & 22.44 & 28.71 & 21.95 & 0.09 \\
\hline
\end{tabular}

\section{Conclusion}

In this study, the performance of three oxidation processes e.g. photocatalysis $\left(\mathrm{TiO}_{2} / \mathrm{UV}\right.$-lamp), DBD-plasma and their combination $\left(\mathrm{TiO}_{2} / \mathrm{UV}\right.$-lamp/DBD-plasma) was described. On the one hand, this work investigates the decomposition of butyraldehyde and ammonia separately. On the other hand, it compares their mixture using three methods selected i.e. (i) DBD-plasma, (ii) photocatalysis, (iii) their combination $\left(\mathrm{TiO}_{2} / \mathrm{UV}\right.$-lamp/DBD-plasma). The combination of plasma and photocatalysis was shown to improve significantly the process efficiency. These improvements were related to the degradation and the mineralization: (i) the removal efficiency of butyraldehyde and ammonia was remarkably enhanced and a synergetic effect was shown for all experimental conditions; (ii) a better performance in mineralization rate was observed. Indeed, $\mathrm{CO}_{2}$ selectivity attained $11 \%$ higher than DBD-plasma alone, and (iii) low ozone concentration was detected. The process validation for the mixture $\left(\mathrm{C}_{4} \mathrm{H}_{8} \mathrm{O} / \mathrm{NH}_{3}\right)$ was also studied in detail. The amounts of ozone were lower than that of single butyraldehyde and ammonia treatment. Ammonia could be decomposed easily via $\left(\mathrm{TiO}_{2} / \mathrm{UV}\right.$-lamp/DBD-plasma) process compared to photocatalysis. At high humidity, the 
competitive behavior between water molecules and butyraldehyde towards the catalytic active sites became higher. This competitive behavior led to the decrease in the butyraldehyde removal and to the decrease of ozone formation during the process. Moreover, butyraldehyde alone and in equimolar mixture $\left(\mathrm{NH}_{3} / \mathrm{C}_{4} \mathrm{H}_{8} \mathrm{O}\right)$ intermediate byproducts are identified. Surface poisoning was observed before applying the combined process. After applying the combination $\left(\mathrm{TiO}_{2} / \mathrm{UV}\right.$-lamp/DBD-plasma), the catalytic active sites were liberated and the pollutants were mineralized. The coupling of the two processes shown in this study is seen to be a promising solution for indoor/outdoor air treatment and needs more investigation in the near future.

\section{References}

[1] ADEME, Pollutions olfactives: origine, législation, analyse, traitement. Ademe, Dunod, Paris, 2005

[2] M. Schiavon, V. Torretta, Andrea, M. Ragazzi, Non-thermal Plasma as an Innovative Option for the Abatement of Volatile Organic Compounds: a Review, Water Air Soil Pollut (2017) 228-388

[3] S. N. Behera, M. Sharma, V.P. Aneja, R. Balasubramanian, Ammonia in the atmosphere: a review on emission sources, atmospheric chemistry and deposition on terrestrial bodies, Environ. Sci. Pollut. Res. (2013) 8092-8131

[4] S. Sultana, A. M. Vandenbroucke, C. Leys, N. De Geyter, R. Morent, Abatement of VOCs with Alternate Adsorption and Plasma-Assisted Regeneration: A Review, Ctalysts (2015) 718-746

[5] C. C. Rodrigues, D. de Moraes Jr., S. W. Nobrega, M. G. Barboza, Ammonia adsorption in fixed bed of activated carbon, Bioresour. Technol. (2007) 886-891 
[6] P. Doggali, Y. Teraoka, P. Mungse, I. Shah, S. Rayalu, N. Labhsetwar, Combustion of volatile organic compounds over $\mathrm{Cu}-\mathrm{Mn}$ based mixed oxide type catalysts supported on mesoporous $\mathrm{Al}_{2} \mathrm{O}_{3}, \mathrm{TiO}_{2}$ and $\mathrm{ZrO}_{2}$, J. Molecular Catal. A (2012) 23-30

[7] Q. Hu, C. Wang, K. Huang, Biofiltration perfermonce and characteristics of high-temperature gaseous benzene, hexane and toluene, Chem. Eng. J. (2015) 689-695

[8] T. Kaosol, N. Pongpat, Ammonia Gas Removal from Gas Stream by Biofiltration using Agricultural Residue Biofilter Medias in Laboratory-scale Biofilter, International Journal of Biological, Biomolecular, Agricultural, Food and Biotechnological Engineering (2011) 281285

[9] G. R. Parmar, N. N. Rao, Emerging Control Technologies for Volatile Organic Compounds, Critical Reviews in Environmental Science and Technology (2009) 41-78

[10] M. Schiavon, M. Schiorlin, V. Torretta, R. Brandenburg, M. Ragazzi, Non-thermal plasma assisting the biofiltration of volatile organic compounds, Journal of Cleaner Production (2017) 498-508

[11] O. Karatum, M.A. Deshusses, A comparative study of dilute VOCs treatment in non-thermal plasma reactor, Chem. Eng. J. (2016) 308-315

[12] M. Bahria, F. Haghighata, S. Rohanib, H. Kazemian, Impact of design parameters on the performance of non-thermal plasma air purification system, Chem. Eng. J. (2016) 204-212

[13] Y. Boyjoo, H. Sun, J. Liu, V. K. Pareek, S. Wang, A review on photocatalysis for air treatment: From catalyst development to reactor design, Chem. Eng. J. (2017) 537-559

[14] Z. Jiang, M. Chen, J. Shi, J. Yuan, W. Shangguan, Catalysis Removal of Indoor Volatile Organic Compounds in Room Temperature: From Photocatalysis to Active Species Assistance Catalysis, Catal. Surv. Asia (2015) 1-16

[15] U. L. Rochetto, E. Tomaz, Degradation of volatile organic compounds in the gas phase by heterogenous photocatalysis with titanium dioxide/ultraviolet light, Journal of the Air \& Waste Management Association (2015) 810-817 
[16] Y. Huang, S.S. Hang Ho, Y. Lu, R. Niu, L. Xu, J. Cao, S. Lee, Removal of Indoor Volatile Organic Compounds via Photocatalytic Oxidation: A short Review and Porspect, Molecules (2016) 1-20

[17] J. Schneider, M. Matsuoka, M. Takeuchi, J. Zhang, Y. Horiuchi, M. Anpo, D.W. Bahnemann, Understanding $\mathrm{TiO}_{2}$ Photocatalysis: Mechanisms and Materials, Chem. Rev. (2014) 9919-9986

[18] J. Karuppiah, E. Linga Reddy, P. Manoj Kumar Reddy, B. Ramaraju, Ch. Subrahmanyam, Catalytic nonthermal plasma reactor for the abatement of low concentrations of benzene, Int. J. Environ. Sci. Technol. (2014) 311-318

[19] S. Gharib-Abou Ghaida, A.A. Assadi, G. Costa, A. Bouzaza, D. Wolbert, Association of surface dielectric barrier discharge and photocatalysis in continuous reactor at pilot scale: Butyraldehyde oxidation, by-products identification and ozone valorization, Chem. Eng. J. (2016) 276-283

[20] W.J. Liang, H.P. Fang, J. Li, F. Zheng, J.X. Li, Y.Q. Jin, Performance of non thermal DBD plasma reactor during the removal of hydrogen sulfide, J. Electrostat. (2011) 206-213

[21] W. Abou Saoud, A.A. Assadi, M. Guiza, A. Bouzaza, W. Aboussaoud, A. Ouederni, I. Soutrel, D. Wolbert, S. Rtimi, Study of synergetic effect, catalytic poisoning and regeneration using dielectric barrier discharge and photocatalysis in a continuous reactor: Abatement of pollutants in air mixture system, Appl. Catal. B: Environ. (2017) 53-61

[22] T. Zhu, R. R. Li, M. F. Ma, X. Li, Influence of energy efficiency on VOCs decomposition in non-thermal plasma reactor, Int. J. Environ. Sci. Technol. (2017) 1505-1512

[23] T. Pham Huu, L. Sivachandiran, P. Da Costa, A. Khacef, Methane, Propene and Toluene Oxidation by Plasma-Pd/c- $\mathrm{Al}_{2} \mathrm{O}_{3}$ Hybrid Reactor: Investigation of a Synergetic Effect, Top. Catal. (2017) 326-332

[24] B. Dou, D. Liu, Q. Zhang, R. Zhao, Q. Hao, F. Bin, J. Cao, Enhanced removal of toluene by dielectrical barrier discharge coupling with $\mathrm{CU}-\mathrm{Ce}-\mathrm{Zr}$ supported $\mathrm{ZSM}-5 / \mathrm{TiO}_{2} / \mathrm{Al}_{2} \mathrm{O}_{3}$, Catalysis Communications (2017) 15-18 
[25] A. A. Assadi, B. Abdelkrim, S. Isabelle, P. Philippe, M. Karimd, W. Dominique, A study of pollution removal in exhaust gases from animal quartering centers by combining photocatalysis with surface discharge plasma: from pilot to industrial scale, Chem. Eng. Process (2016) 1-6

[26] D. Mei, X. Zhu, C.Wu, B. Ashford, Paul T. Williams, X. Tu, Plasma-photocatalytic conversion of $\mathrm{CO}_{2}$ at low temperatures: Understanding the synergistic effect of plasmacatalysis, Appl. Catal. B: Environ. (2016) 525-532

[27] A. A. Assadi , A. Bouzaza, C. Vallet, D. Wolbert, Use of DBD plasma, photocatalysis, and combined DBD plasma/photocatalysis in a continuous annular reactor for isovaleraldehyde elimination-Synergetic effect and byproducts identification, Chem. Eng. J. 254 (2014) 124132

[28] A. Maciuca, C. Batiot-Dupeyrat, J.M. Tatibouët, Synergetic effect by coupling photocatalysis with plasma for low VOCs concentration removal from air, Appl. Catal. B: Environ. (2012) 432-438

[29] I. Aouadi, J.M. Tatiboue, L. Bergaoui, $\mathrm{MnOx} / \mathrm{TiO}_{2}$ Catalysts for VOCs Abatement by Coupling Non-thermal Plasma and Photocatalysis, Plasma Chem Plasma Process (2016) $1485-1499$

[30] A.A. Assadi, A. Bouzaza, M. Lemasle, D. Wolbert, Removal of trimethylamine and isovaleric acid from gas streams in a continuous flow surface discharge plasma reactor, Chem. Eng. Res. Des. (2015) 640-651

[31] G. Costa, A.A. Assadi, S. Gharib-Abou Ghaida, A. Bouzaza, D. Wolbert, Study of butyraldehyde degradation and by-products formation by using a surface plasma discharge in pilot scale: Process modeling and simulation of relative humidity effect, Chem. Eng. J. (2016) 785-792

[32] S. Rtimi, O. Baghriche, Ro. Sanjines, C. Pulgarin, M. Bensimon, J. Kiwi, TiON and TiON-Ag sputtered surfaces leading to bacterial inactivation under indoor actinic light, J. Photochem. Photobiol A: Chem. 256 (2013) 52-63 
[33] S. Rtimi, C. Pulgarin, M. Robyr, A. Aybush, I. Shelaev, F. Gostev, V. Nadtochenko, J. Kiwi, Appl. Catal. B: Environ. 208 (2017) 135-147.

[34] D. Shirley, Corrections of electrostatic charged species in SP-spectroscopy, Physical Review B5 (1972) 4709-4716.

[35] Lexuan Zhong, James J. Brancho, Stuart Batterman, Bart M. Bartlett, Christopher Godwin, Experimental and modeling study of visible light responsive photocatalytic oxidation (PCO) materials for toluene degradation, Appl. Catal. B: Environ. (2017) 122-132

[36] T. Martinez, A. Bertron, G. Escadeillas, E. Ringot, V. Simon, BTEX abatement by photocatalytic $\mathrm{TiO}_{2}$-bearing coatings applied to cement mortars, Building and Environment (2014) 186-192

[37] O. Debono, V. Hequet, L. Le Coq, N. Locoge, F. Thevenet, VOC ternary mixture effect on ppb level photocatalytic oxidation: Removal kinetic, reaction intermediates and mineralization, Appl. Catal. B: Environ. (2017) 359-369

[38] S. Lu, L. Chen, Q. Huang, L. Yang, C. Du, X. Li, J. Yan, Decomposition of ammonia and hydrogen sulfide in simulated sludge drying waste gas by a novel non-thermal plasma, Chemosphere 117 (2014) 781-785

[39] L. Xia, Li Huang, X. Shu, R. Zhang, W. Dong, H. Hou, Removal of ammonia from gas streams with dielectric barrier discharge plasmas, Journal of Hazardous Materials (2008) $113-119$

[40] G. Maxime, A.A. Amine, B. Abdelkrim, W. Dominique, Removal of gas-phase ammonia and hydrogen sulfide using photocatalysis, nonthermal plasma, and combined plasma and photocatalysis at pilot scale, Environ. Sci. Pollut. Res. (2014) 13127-13137

[41] Y. Shi, Z. Shao, T. Shou, R. Tian, J. Jiang, Y. He, Abatement of Gaseous Xylene Using Double Dielectric Barrier Discharge Plasma with In Situ UV Light: Operating Parameters and Byproduct Analysis, Plasma Chem Plasma Process (2016) 1501-1515

[42] S. Rtimi, S. Giannakis, R. Sanjines, C. Pulgarin, M. Bensimon, J. Kiwi, Insight on the photocatalytic bacterial inactivation by co-sputtered $\mathrm{TiO}_{2}-\mathrm{Cu}$ in aerobic and anaerobic conditions, Appl. Catal. B: Environ. 182 (2016) 277-285 
Graphical abstract:

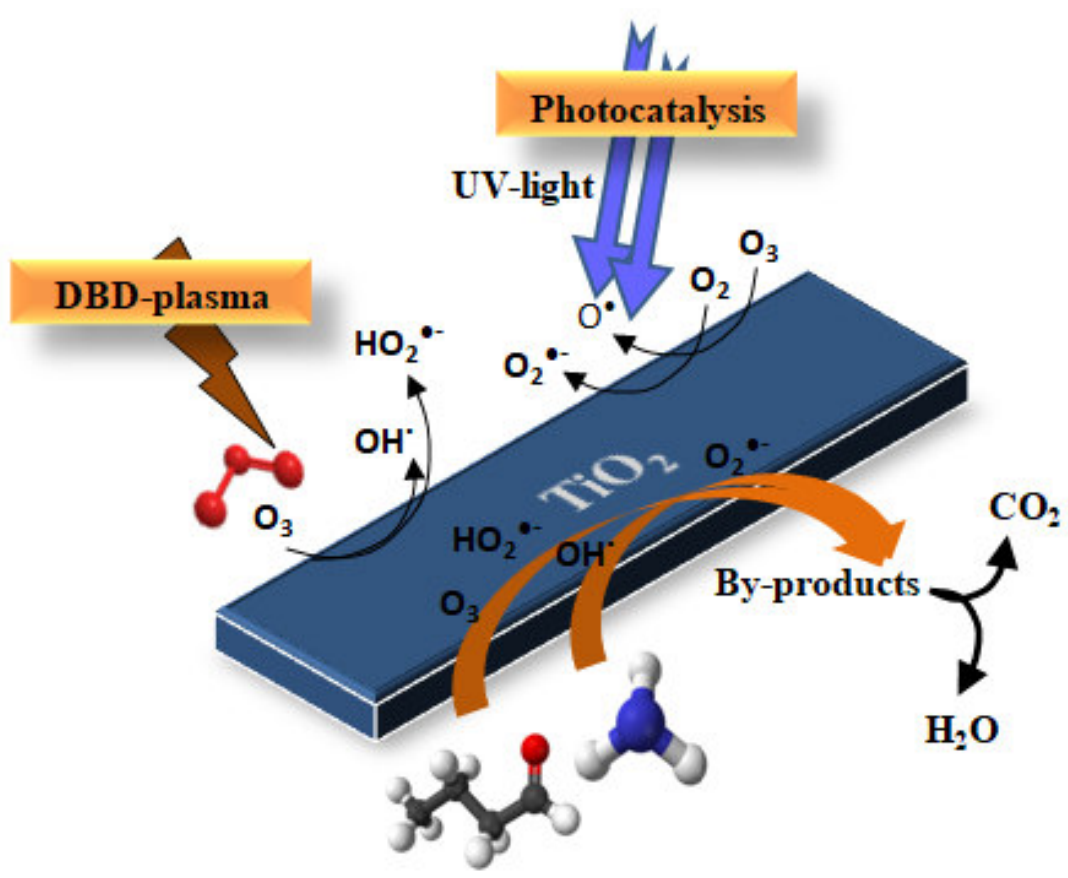




\section{Highlights:}

1. Simultaneous degradation of butyraldehyde and ammonia is performed.

2. Synergistic effects of plasma-photocatalysis is observed to mineralize pollutants.

3. Impact of relative humidity on pollutant and ozone degradation is studied.

4. High $\mathrm{CO}_{2}$ selectivity and a remarkable decrease of ozone concentration were observed.

5. Degradation by-products of $\mathrm{C}_{4} \mathrm{H}_{8} \mathrm{O} / \mathrm{NH}_{3}$ were identified during plasma-photocatalysis. 